\title{
Euroscepticism of the Conservative Party and the Labour Party during the 2015 general election campaign
}

\author{
Ondřej DOLEŽEL*
}

\begin{abstract}
The United Kingdom had been a part of the European integration process since 1973. The 2016 referendum, in which British citizens voted to leave the EU, could be considered as an imaginary peak of tensions between the political priorities of the UK and the EU. The article therefore addresses the attitude of two major British political parties, the Conservative Party, and the Labour Party, towards European integration during the 2015 general election campaign. The article analyses the stance of these parties towards the EU by using two typologies of Euroscepticism. The first theoretical framework of Søren Riish $\phi j$ determines the content of Euroscepticism. The second developed by Aleks Szczerbiak and Paul Taggart focuses on the intensity of its manifestation. The Analytical part is devoted to the research of the party positions themselves. The main goal is to answer whether the parties can be defined as hard or soft Eurosceptic. Additionally, it will be possible to compare the intensity of their Eurosceptic stances and analyse their attitude to the referendum pledge.
\end{abstract}

Keywords: Euroscepticism; Conservative Party; Labour Party; United Kingdom; European Union

\section{Introduction}

The United Kingdom's opposition to certain features of the European integration process had been present with varying degrees of intensity since the negotiations on the European Coal and Steel Community. A long-term dissatisfaction with the level of integration, the emergence of other political rivals and internal pressures within the Conservative Party ultimately led to David Cameron's referendum pledge in 2013. In the event of victory in the 2015 general

\footnotetext{
* Ondřej DOLEŽEL is PhD student at the Department of Political Science and European Studies at Palacký University in Olomouc, Czech Republic; email: ondrej.doleze102@upol.cz.
} 
election, Cameron promised to negotiate revised EU membership terms and subsequently call an in/out referendum. Although he managed to negotiate this revision with European partners, British voters chose to leave in June 2016. Therefore, Euroscepticism needs to be addressed, as its rise eventually led to something unprecedented. For the first time in history of European integration, the path to disintegration had been opened. This article will provide a case-oriented empirical analysis of this final stage of British partisan Euroscepticism by using a combinatory theoretical approach to stances during the 2015 election campaign period.

\section{Euroscepticism: theoretical conceptualization}

Euroscepticism initially emerged as a phenomenon whose origins can be traced back to 1985 and 1986 in articles of the British newspaper The Times. Margaret Thatcher's Bruges speech in 1988 marked the time when opposing integration started to crystallize in a mainstream way. The Oxford Dictionary lists its origins in the early 1990s, specifically in 1992 in The Economist. The EU's expanding political competences had adequately multiplied the potential sources of resistance to the integration trend, which had gradually become evident also in continental Europe. But what exactly does it mean if a public authority, institution, or political party is labelled as Eurosceptic? The increasing political importance and use of this term boosted scientific interest which led to emerging literature seeking to define and understand it more clearly. Thus, diverse theoretical approaches were elaborated, operating with different levels of intensity, scales and contents of origin (Geddes, 2013, p. 219; Gifford, 2014, pp. 1-2; Harmsen and Spiering, 2004, pp. 13, 18; Tournier-Sol and Gifford, 2015, p. 2; Usherwood and Startin, 2013, p. 3).

One of the first such efforts was the article by Paul Taggart in 1998. His later collaboration with Aleks Szczerbiak ${ }^{1}$ led to a refinement of the distinction between "hard" and "soft" forms of Euroscepticism. The reformulated version reads as follows: Hard Euroscepticism can be defined as a principled opposition to the project of European integration as embodied in the EU, in other words, based on the ceding or transfer of powers to supranational institutions such as the EU; Soft Euroscepticism is an opposition to the EU's current or future planned trajectory based on the further extension of competencies that the EU is planning to make (Gifford, 2014, p. 2; Harmsen and Spiering, 2004, p. 18; Szczerbiak and Taggart, 2008b, p. 3).

These authors also developed evaluation methods to identify these positions. The first option of hard Euroscepticism is to evaluate a party as a "single-issue anti-

\footnotetext{
${ }^{1}$ These authors recently elaborated the impact of Brexit, migration crisis and eurozone crisis on the rise of Euroscepticism in individual European states, see Szczerbiak and Taggart (2018b, pp. 1194-1214).
} 
EU party", in which case we assume that the entity exists primarily to mobilize against EU membership or EU in general. In the second option, the opposition to the EU is framed in language that criticizes it as too capitalist, socialist, neo-liberal or bureaucratic, depending on the subject's ideological status (communist, conservative, socialist or populist). Such party considers the conditions of EU membership as incompatible with the current trajectory of the European project or states unattainable membership terms, which can be defined as de facto opposing to EU membership. Identifying soft Eurosceptics, on the other hand, is based on capturing those positions that constitute real scepticism about the way the EU is currently developing. According to Szczerbiak and Taggart, if we assume that the contemporary project of European integration is being pushed onwards and that the status quo is very rarely defended, supporting the EU as it currently exists and opposing any further integration can be considered effectively Eurosceptic (Szczerbiak and Taggart, 2008a, pp. 7-8). The Academic appeal of this framework lies in its practical application to specific cases. Another strong point is the fact that this typology had been confronted with critical reflection, whereupon it had been revised, retaining its clarity and comprehensibility (Kaniok, 2006, p. 21). Nevertheless, supplementary criticism can be directed to the broad definition of methodology to identify soft Euroscepticism, which lacks the capacity to capture additional variations and can lead to similar classification of two qualitatively different entities.

Other theoretical framework, developed by Søren Riishøj, is based on similar positions to the original classification of Taggart and Szczerbiak. However, it produces a different scale, which does not work as much with the degree of Euroscepticism as with its origin (Kaniok, 2006, p. 20). It includes nine categories of Euroscepticism depending on the areas on which critical stances are adopted:

Identity-based involving a contradiction between national identity and European identity, including a fear of being "absorbed" by the supranational institution like the EU and thereby losing national sovereignty; Cleavagebased linked to main dividing lines in society, including socio-economic cleavages between "winners" versus "losers"; Policy-based showing resistance against concrete policies and single issues; Institutionally-based on the discrepancy of legitimacy of national versus EU institutions; National interest-based on contradiction between common European goals and national goals, including a situation of defending vital national interests in spite of weakening of the common European project; Experience based on the feeling that negotiations on EU membership have been unfair and asymmetric; Partybased formed top-down from political parties and charismatic political leaders using either neoliberal ("thatcheristic"), anti-modern traditionalist or leftpopulist argumentation; Atlantic-based on the feeling of a contradiction or dilemma between pro-Americanism and pro-Europeanism, e.g. in case of the establishment of a common European foreign and security policy; Practice- 
based on no principal resistance to the EU and Europeanisation, but Europeanism is defined in a "national" way and different from that of Brussels and demanded by the EU according to the "mainstream" interpretation of the Copenhagen criteria (Riishøj, 2007).

The problem with Riishøj's typology lies in the definitions of some categories $^{2}$, which make them either unclear or poorly applicable. This undermines the practical overall use of this theory. Besides, contrary to the previous case, it does not have the capacity to capture Eurosceptic positions in terms of their intensity.

Petr Kopecký and Cas Mudde similarly based their theory on criticism of the original Taggart and Szczerbiak typology, as they considered the definition of soft Euroscepticism too inclusive (Szczerbiak and Taggart, 2008a, p. 225). The second complaint was directed at the issue of EU membership. In their view, this is not the key point dividing hard and soft Eurosceptics. Kopecký and Mudde therefore put forward an alternative categorization of four attitudes:

Euroenthusiasts support European integration and the current trajectory of the EU; Europragmatists oppose European integration but support the current trajectory of the EU; Eurosceptics support European integration but reject EU's trajectory; Eurorejects are opponents of European integration and reject current trajectory of the EU (Kopecký and Mudde, 2002, pp. 302-303).

This typology contains the hard-to-defend concept of Euroscepticism as an opinion which, while opposing today's trajectory of the integration process, essentially supports European integration as such (Kaniok, 2006, pp. 15, 21). Furthermore, the Europragmatic category is almost devoid of practical use. Its definition may seem a semantic contradiction because it is cumbersome to define an attitude that rejects European integration but supports today's EU trajectory, an embodiment of the integration process. Although the concept of Kopecký and Mudde evokes an aesthetic and symmetrically compact impression, it has not led to creation of practically applicable framework lacking excessive controversies.

Chris Flood and Simon Usherwood have also created a scale that does not include only negative positions. Euroscepticism is considered as only one end of the spectrum, which needs to be continuous and includes different degrees of support

\footnotetext{
${ }^{2}$ In this respect, the most problematic categories appear to be cleavage-based, party-based and practice-based Euroscepticism. Cleavage-based Euroscepticism, unlike others, does not characterize opposing any area of European integration, but describes the divergence of attitudes based on cleavage lines. Therefore, it is not categorical, but a comparative instrument in its nature, telling us about tendencies depending on a segment of society. Partybased Euroscepticism basically duplicates the categories already established. If a party holds a specific political position, it is natural that it is articulated by its leader as well. In principle, it is not the origin within the party, but the content that matters. Practise-based is probably the most problematic, mainly because of the lack of a clear and applicable definition despite Riishøj's reference to its manifestation in Slovakia under Mečiar.
} 
for European integration (Szczerbiak and Taggart, 2008a, p. 6). It aims to provide a tighter specification that allows the categorization of party shifts over time. The concept has the following six grades: rejectionist, revisionist, minimalist, gradualist, reformist and maximalist (Flood and Usherwood, 2007, p. 6). The main weakness of this typology is the fact that the brief definition of some degrees may cause their overlap. Thus, we could identify more than one category at the same time in case of some parties, which significantly weakens its accuracy. For further reflection of this scale, see Szczerbiak and Taggart (2018a, pp. 11-21) and Vasilopoulou (2018, pp. 22-35). Later cooperation of Simon Usherwood with Nick Startin led to a classification of four different types of Eurosceptic parties; single-issue prosovereignty parties, radical right parties, left-wing parties beyond the mainstream left and mainstream parties increasingly adopting a "soft Eurosceptic" discourse (Usherwood and Startin, 2013, pp. 5-6).

A scale-based typology using the original concept of hard and soft Euroscepticism was also designed by Nicolo Conti and Luca Verzichelli. But their concept involves five levels: hard Euroscepticism, soft Euroscepticism, no commitment/no mention, functional Europeanism and identity Europeanism (Conti, 2003, p. 17). The problem with this theory is that it lacks any innovation in research into Euroscepticism (Kaniok, 2006, p. 22). It merely included the already existing distinction but did not contribute to its deeper elaboration or completion. Thus, it can be considered as an extension of the concept of Taggart and Szczerbiak by incorporating positive stances. Moreover, as in the previous case, there remains the problem that these categories may overlap. We could ask if there is any need to classify a case that, in fact, has no position on European integration at all. Further insight into this research is provided by Leruth et al. (2018).

\section{Methodology of analysis}

Having used a combinatory theoretical approach, it will be possible to answer the research question whether the Conservative Party and the Labour Party profiled as softly Eurosceptic during the 2015 general election campaign. Although the definition of soft Euroscepticism is given, based on the above-mentioned criticism, there remains a lack of a more comprehensive method of evaluating this position. In this respect, it seems appropriate to complement it by using the framework of Søren Riishøj (2007), where Euroscepticism is not classified on basis of intensity, but according to the specific areas in which criticism is expressed. Thus, it will be possible to identify soft Euroscepticism in the case of a party showing one or more of Riishøj's categories of identity-based, policy-based, institutionally-based, national interest-based or Atlantic-based Euroscepticism. Because of the criticism made on this typology, the following will be eliminated: practice-based, partybased, cleavage-based Euroscepticism and since the UK had been a member of the EC/EU since 1973, it also makes no sense to search for manifestations of experience- 
based Euroscepticism. On the other hand, defining a party as hard Eurosceptic will depend either on the identification as a single-issue anti-EU party whose existence and political activity is primarily aimed at principled opposing to the EU; or if the available sources show that, because of its ideology, the party imposes unreachable conditions of consent to EU membership.

The research of selected cases will be based on empirical-analytical approach. The aim is to provide their understanding, for which the theoretical, temporal, and thematic boundaries have been established, taking into account the situational context and historical background. The subject is defined by the analysis and categorization of pre-election European rhetoric of the Conservative and Unionist Party and the Labour Party. The time covered is defined by the period of the election campaign before the 2015 general election. The primary sources will be the manifestoes, as they pose official positions of these parties, but they need to be complemented by secondary literature and media sources, providing statements of individual party leaders, historical context and capturing cleavages within these parties.

\section{Conservative and Unionist Party}

In December 2005, David Cameron was elected leader of the Conservative Party during its long-term stay on the opposition benches. For the first time since 1992, the party managed to return to power after winning in May 2010 general election. The European policy of Cameron's cabinets (2010-2016) ${ }^{3}$ demonstrated no change in traditional intra-party ambivalence in positions to the EU. A combination of internal tensions within the party and external pressure from other Eurosceptic rivals, mainly UKIP, had become major forces resulting in the Prime Minister's first public promise on 23 January 2013, that in case of winning the 2015 general election, the government would hold a referendum on British membership in the EU by the end of 2017. However, David Cameron's pledge must be seen in the context of a more comprehensive strategy to maintain, or rather strengthen, the unity of his party and government. A certain precedent of such tactics had been established in 1975, when the Labour Party called the first such referendum. Taking account of the circumstances of Cameron's election as leader of the party, together with the election results in 2010, the vulnerability of his position had been revealed. Therefore, the 2013 referendum pledge was also intended to strengthen his own position (Alexandre-Collier, 2015a; Alexandre-Collier, 2015b, p. 153; Baker et al., 1994; Geddes, 2013, pp. 72, 74-75, 236).

\footnotetext{
${ }^{3}$ During the first term in coalition government with Liberal Democratic Party (2010-2015). Cameron's second Conservative-only cabinet took office in years 2015-2016. Their European policy is described by e.g. Geddes (2013, pp. 100-111, 248-251) and Gifford (2014, pp. 155-170).
} 


\subsection{Stance of the Conservatives on the EU during the 2015 general election campaign}

These factors were reflected in the overall form and content of the 2015 Manifesto. Its European policy can be found in the section Real change in our relationship with the European Union, containing the promise to deliver the referendum. In addition, it declares a commitment to preserve the British pound and keep the country outside the eurozone. These promises were nothing new in electoral rhetoric. David Cameron, still in the role of opposition leader in 2009, criticized parliamentary ratification of the Lisbon Treaty, demanded new power guarantees for the United Kingdom and promised to introduce a legal safeguard committing further transfer of powers to popular consent ${ }^{4}$ (Cameron, 2009; Conservatives, 2015, p. 72).

The 2015 Conservative Manifesto explicitly states that the EU excessively interferes in everyday life, it is too bureaucratic and undemocratic. To avoid a solely negative message, the text tries to highlight beneficial aspects of membership. A clear yes is expressed to the single market, its digitalization, free trade and cooperation, but it is additionally mentioned that crucial national interests must be decisively guaranteed, whether inside the eurozone or not. In this respect, the party openly opposed certain features of the EU. A clear no is stressed to 'ever closer union', to a constant flow of power to Brussels, to a European army and to the adoption of the euro or participation in eurozone bail-outs. As a tangible proof of success, the text reminds the steps the Conservatives had already taken. The given example is Cameron's decision not to join the Fiscal Compact, a political move welcomed by the Eurosceptic-minded party members. Opinion polls similarly indicated support for Prime Minister's position, signalling a better perspective for the ambition to revise the terms of UK's membership (Conservatives, 2015, pp. 7273; Gifford, 2014, p. 164; Miller, 2012, p. 1).

The Manifesto contains constructive language towards certain economic aspects of the EU. An interest is expressed in the prospect of expanding the single market, removing remaining trade barriers and improving supervision of the financial services industry. The text urges for lowering EU spending, reform of the Structural Funds and focusing EU money on promoting jobs and growth. Conservatives make a minimalist statement on the Common Agricultural Policy (CAP) by just briefly announcing to push for its further reform. Only a subsequent government document, promising to promote fewer agricultural inspections, simpler advising and a review of complex environmental requirements, offers some clarification on what will help improve the CAP (Conservatives, 2015, pp. 21, 73; Gov.uk, 2015).

\footnotetext{
${ }^{4}$ This pledge was delivered by introducing The European Union Act entering in force in 2011 (Geddes, 2013, p. 106; Hodson and Maher, 2014, p. 646).
} 
One of the crucial pledges can be found in the migration section of the Manifesto. Conservatives declared an intention to insist that EU immigrants must live in Britain and contribute to the budget for at least four years prior to claiming tax credits, child benefit or social housing. This promise had not escaped the attention of the European Commission, which warned that these claims were likely to be rejected because they posed an unacceptable violation of the fundamental principle of free movement of people. Cameron said in November 2014, in an increasingly electoral atmosphere: "EU migrants should have a job offer before they come here. UK taxpayers will not support them if they don't." This example clearly shows how the terms of immigration and free movement of people within the EU are easily interchangeable in Conservatives' rhetoric (Conservatives, 2015, p. 30; Watt, 2015).

The party insisted in the Manifesto to redirect the flow of powers from Brussels, not to Brussels. In this regard, it intended to make several changes. First and foremost, there is an interest in ending Britain's commitment to 'ever closer union'. Furthermore, according to the Conservatives, national parliaments should be able to work together to block unwanted European legislation. In addition, they wanted to ensure that defence policy remained firmly under British national control, maintaining NATO and transatlantic relations as the cornerstone of British defence and security policy. This led to another dispute with the Commission. In early 2015, Commission President Juncker called for the creation of a common EU army. Cameron had repeatedly reassured the Parliament that this would never receive Britain's support. The government's position had explicitly declared that defence policy was considered a national responsibility, not an EU responsibility. Together with the promise to protect the British economy from any further integration of the euro area, the Conservatives declared that they would negotiate a new UK membership agreement after the elections and then ask the British people whether they wanted to stay in the EU on this reformed basis or leave (Conservatives, 2015, pp. 72-73; Robinson and Shotter, 2015).

The Conservative Party managed to win the 2015 general election and gain an overall majority of seats in the House of Commons for the first time since 1992 (330 out of 650) (Hawkins et al., 2015, pp. 7, 26). Thus, the prospect of a single party cabinet guaranteed a politically comfortable path to deliver election promises. On 10 November 2015, Cameron addressed a letter to the President of the European Council, Donald Tusk, listing the changes he intended to negotiate in the terms of British membership (Cameron, 2015, pp. 1-5). The agreement was reached at the European Council of 18-19 February $2016^{5}$ (European Council, 2016b), whereupon the cabinet decided to hold the referendum in June 2016 (Uberoi, 2016, p. 4). David Cameron then embarked on a campaign to persuade the British to vote for remaining. However, traditional inter-party ambivalence manifested itself also on this occasion. Boris Johnson, former Mayor of London, along with Michael Gove, Secretary of

\footnotetext{
${ }^{5}$ As laid down in European Council conclusions (2016a).
} 
State for Justice, and other supporters of leaving started a Vote Leave campaign. ${ }^{6}$ European integration had split the party again at the top level. 24 cabinet members supported staying in the EU, but six were against. 185 Conservative Members of Parliament declared to vote for remaining, but a group of 138 Conservative MPs declared the opposite ${ }^{78}$.

\section{Labour party}

The policy on European integration was not a unifying and conflict-free factor within the Labour Party either. The most pro-European turn took place under Tony Blair $^{9}$, who led the party to a triumphant election victory in 1997. This approach, particularly regarding the adoption of the single currency, had noticeably cooled after Gordon Brown, Blair's Chancellor of the Exchequer, had taken the lead. The loss in 2010 general election interrupted 13 years of Labour government and brought Ed Miliband to the responsibility to lead the party to another election test in 2015 (BBC ${ }^{10}$; Gifford, 2014, p. 147; Oppermann, 2008, pp. 156, 161, 172).

\subsection{Stance of the Labour Party on the EU during the 2015 general election campaign}

The Labour Party's approach had shifted to deeper criticism of the EU when Ed Miliband took the lead. The general principle of the attitude towards the EU at that time can be expressed in the following Manifesto statement: "We will work to reform the European Union, and we will retain our membership of it." These preferences reflected what Miliband stated as leader of the opposition already in November 2012. In addition to highlighting the economic, political and strategic reasons for staying in the EU, he said: “...there is an urgent imperative for us to reform the European Union (...) We also need to complete the single market. Especially in areas which could benefit Britain, from digital technologies to energy." Similarly, Douglas Alexander, the Shadow Foreign Secretary, expressed his concerns that Europe was not meeting the expectations of its citizens, which must be

\footnotetext{
${ }^{6}$ Vote Leave (2016), About the campaign (retrieved from http://www.voteleavetakecontrol. org/campaign.html).

${ }^{7}$ The complete list of Conservative Party members who publicly declared either to support or to oppose remaining in the EU is provided in the article "EU vote: Where the cabinet and other MPs stand" (BBC, 2016).

${ }^{8}$ BBC (2016), EU vote: Where the cabinet and other MPs stand, 22 June (retrieved from http://www.bbc.com/news/uk-politics-eu-referendum-35616946).

${ }^{9}$ Analysis of Labour European policy under Tony Blair can be found in Gifford (2014, pp. 131-154).

${ }^{10}$ BBC (2010), Gordon Brown: I was ready to quit over euro decision, 8 December (retrieved from http://www.bbc.com/news/uk-politics-11947831).
} 
changed if it was to retain political legitimacy. After Cameron's referendum pledge in 2013, Alexander, in a speech to Chatham House, clarified Labour preference to reform Europe, not exit from Europe. This statement, which can be considered as the most minimalistic summary of Labour stance, was reflected during the 2015 general election campaign (Cracknell et al., 2011, p. 24; Gifford, 2014, p. 168; Labour Party, 2015, pp. 15-16; Schnapper, 2015, pp. 123-125).

The main section of the Manifesto devoted to European policy is intertwined with the chapter Standing up for Britain's interests in Europe and the world, where the party mentions the ongoing economic uncertainty in the eurozone. Labour identifies itself as an internationalist party and believes that Britain must engage in global challenges. In this respect, it uses its opposition role to blame the Conservative Party for damaging British interests and turning their backs on Europe. Therefore, it intended to continue to defend the EU, looking outward to promote stability, peace and prosperity on its borders (Labour Party, 2015, pp. 98-99).

Another example of positive attitude towards the EU is a declared conviction, that "...our membership of the European Union is central to our prosperity and security. It is why we will work to change the EU, so that it operates in the best interests of our country." According to the Manifesto, the economic benefit of membership is "overwhelming". It states that more than three million jobs in the UK are linked to trade with the EU, almost half of Britain's trade and foreign investment comes from the EU and that competition in the single market strengthens the competitiveness and innovation of firms in all parts of the UK economy. It also helps to boost living standards of people across Britain and encourages the inflow of capital and investment. The party expresses its belief that its reform proposals will help create an EU focused on jobs and growth, not just on a policy of austerity and rising unemployment. In the sense of reducing spending, it named the CAP reform and the review of EU funding. In the case of the single currency, there is an explicit statement: "We will not join the Euro, and we will ensure EU rules protect the interests of non-Euro members." This was in line with Miliband's broad speech in March 2014, when he, like the Conservatives, stressed the need to protect national interests of those outside and inside the eurozone (Labour Party, 2015, pp. 101-102; Miliband, 2014).

Moreover, we can observe a striking degree of consensus with the Conservative Party on immigration policy. The Labour Manifesto initially speaks in a positive way, mentioning that immigration had made a significant contribution to British economic and social life, but adds that it must be properly controlled, as migrants from the EU should not be able to claim benefits until living in Britain for at least two years. This had led to the promise to ensure a reform of immigration and social rules, which should include the promotion of stronger transitional controls, and thus, allow a better management of the influx of workers from the new member states of the EU. When Miliband spoke at Chatham House of the reform, many points of his speech showed a curious correspondence with Cameron's European policy on 
immigration, social benefits, and empowering national parliaments on EU issues. This consensus was confirmed by the end of 2013, when prospects for an increase in Romanian and Bulgarian immigration due to the end of the transitional period for free movement from these countries had begun to resonate within the British political system. The efforts of the government coalition to tighten up social benefits were also supported by the opposition Labour (Gifford, 2014, p. 169; Labour Party, 2015, pp. 14, 102-103; Schnapper, 2015, p. 127).

The 2015 Labour Manifesto expressed an interest to open up the EU decisionmaking process and implement institutional reforms. In this area, they planned to strengthen the influence of national parliaments over European legislation. The text reminded that the plan was not to take Britain out of Europe, but it intended to introduce a legislative safeguard to ensure that it would not be possible to transfer powers from Britain to the EU without the consent of the British public in a referendum ${ }^{11}$. Paradoxically, the Manifesto thus reflected the same principle that David Cameron, as the opposition leader then, stated in his speech in 2009. In addition to a common preference for a more intergovernmental principle of EU decision-making, we can find another significant consensus between Miliband's Labour and the Conservative party. This includes attitudes towards different areas of EU competence such as the common currency, the CAP, enlargement and the Common Foreign and Security Policy (Cameron, 2009; Labour Party, 2015, pp. 102103; MacMillan, 2015, pp. 196-197).

Nevertheless, Labour suffered another defeat in the May 2015 general election and gained only 232 seats (Hawkins et al., 2015, p. 28). After the Conservative cabinet scheduled the referendum for June 2016, the new Labour leader Jeremy Corbyn declared: "Labour is convinced that a vote to remain is in the best interests of the people of this country." Compared to his predecessors, however, the new leader received criticism for sounding reluctant on remaining, especially because of his objection that the EU was acting as a free market, and additionally because he voted to leave in the 1975 referendum. Corbyn did not forget to call for a reform as well. He said the EU should be more democratic, strengthen workers' rights, social and environmental protection and focus less on austerity and privatization. Labour suffered twice before the referendum: firstly, from a tragic assassination of MP Jo Cox, a supporter of membership; and secondly, from intra-party fractioning. Although 218 Labour MPs declared to vote to remain, a ten-member group of Labour

\footnotetext{
11 The Conservative Party came with a similar pledge in the 2010 Manifesto. This was the so-called referendum lock. On this basis, the approval of any future treaty change strengthening the EU's competences would have to be a subject of popular vote. This mechanism was also meant to be a safeguard against the adoption of the euro without a referendum. Following the establishment of the coalition cabinet in 2010, this European Union Act came into force in July 2011 (Conservatives, 2010, p. 113; Geddes, 2013, pp. 104106; Hodson and Maher, 2014, p. 646).
} 
MPs publicly expressed their reasons to vote leave ${ }^{12}$ (BBC, 2016; Corbyn, 2016a; Corbyn, 2016b; Goodwin, 2016; Rettman, 2015).

\section{Conclusions}

Based on the chosen theory, it is possible to classify the stances of both parties. Institutionally-based Euroscepticism of the Conservatives can be detected in criticism of the excessively undemocratic nature of the EU. Features of Atlanticbased scepticism are displayed in emphasizing transatlantic relations and rejecting integration of defence policy. A key manifestation of national interest-based category was the rejection of the principle of ever closer union and the transfer of powers to the supranational level of the EU. The most tangible policy-based cases are the attitudes towards the euro, alongside with deeper monetary integration and free movement of people. On the other hand, the Labour Party shows two categories: policy-based, in particular by rejecting the euro and in the case of free movement of people; and, at the same time, national interest-based, due to conditioning further transfer of competences to the EU level with a referendum. Therefore, both parties demonstrated a qualified opposition to the integration trend in various areas. The research question was whether the Conservative Party and the Labour Party profiled as softly Eurosceptic during the 2015 general election campaign. The Labour Party profiled itself as soft Eurosceptic, even though a fraction supporting leaving had emerged prior to the referendum. Similarly, the Conservative Party can also be identified as soft Eurosceptic despite the group of cabinet members and MPs which, in contradiction with the official position, advocated withdrawal. Cameron's preelection strategy was to promise to negotiate freer terms for British membership and then, with public approval, to remain in the EU. Therefore, both parties fall within the same theoretical category. It is worth highlighting that the advantages of EU membership are seen primarily in terms of economic benefits in both manifestoes. The importance of the EU as a political player in the global system is emphasized by Labour. Moreover, the call for EU reform is stressed with noticeable differences in political strategy. While the Conservatives expressed their dissatisfaction with the current level of integration, which they were going to put to the test of popular consent, Labour announced that the referendum should only take place if there was a further transfer of powers to the EU. Thus, the Labour referendum pledge was conditional in relation to the ongoing process of European integration, not in relation to electoral victory.

These conclusions show us the limitation of the use of Taggart and Szczerbiak typology. Although it has a reliable definition to capture the intensity of opposition

\footnotetext{
12 The complete list of Labour Party members who publicly declared either to support or to oppose remaining in the EU is provided in the article "EU vote: Where the cabinet and other MPs stand" (BBC, 2016).
} 
against European integration, including intra-party fractions, it lacks the capacity to identify Euroscepticism in terms of the origin of its content. The consequence may lead to identical classification of two or more entities within the same category of this theoretical framework despite their obvious qualitative differences. Such deficiency could be overcome by combinatory approach to another typology capable of capturing sectoral nature of Eurosceptic political argumentation. This poses a challenge for further research in Euroscepticism, but, as shown in the analysis, the adjusted form of Riishøj's distinction may serve such purpose.

Acknowlegment: This work was supported by the Ministry of Education, Youth and Sports, grant IGA_FF_2018_032 (Vybrané problémy mezinárodních vztahů a mezinárodní bezpečnosti).

\section{References}

Alexandre-Collier, Á. (2015a), Euroscepticism under Margaret Thatcher and David Cameron: From Theory to Practice, Observatoire de la societe britannique, 17, pp. 115-133. https://doi.org/10.4000/osb.1778

Alexandre-Collier, Á. (2015b), The Temptation of Populism in David Cameron's Leadership Style, in: Alexandre-Collier, Á. and Vergniolle de Chantal, F. (eds.), Leadership and Uncertainty Management in Politics, Basingstoke: Palgrave, pp. 141-56. https://doi.org/10.1057/9781137439246

Baker, D. Gamble, A. and Ludlam, S. (1994), The parliamentary siege of Maastricht 1993: Conservative divisions and British ratification, Parliamentary Affairs, 47(1), pp. 37 59. https://doi.org/10.1093/oxfordjournals.pa.a052460

Cameron, D. (2009), Full text: Cameron speech on EU, BBC, 4 November (retrieved from http://news.bbc.co.uk/2/hi/8343145.stm).

Cameron, D. (2015), A new settlement for the United Kingdom in a reformed European Union, 10 Downing Street, 10 November (retrieved from https://g8fip1kplyr33r3krz5b97d1-wpengine.netdna-ssl.com/wpcontent/uploads/2015/11/letter.pdf).

Conservatives (2010), Invitation to Join the Government of Britain. The Conservative Manifesto 2010 (retrieved from http://conservativehome.blogs.com/files/ conservative-manifesto-2010.pdf).

Conservatives (2015), The Conservative Party Manifesto 2015: Strong Leadership, a Clear Economic Plan, a Brighter, More Secure Future (retrieved from http://ucrel.lancs.ac.uk/wmatrix/ukmanifestos2015/localpdf/Conservatives.pdf).

Conti, N. (2003), Party Attitudes to European Integration: A Longitudinal Analysis of the Italian Case, SEI Working paper No 70 (retrieved from https://www.sussex.ac.uk/webteam/gateway/file.php?name=epern-working-paper13.pdf\&site=266). 
Corbyn, J. (2016a), Europe needs to change... but I am voting to stay: Corbyn's full speech on the EU, Labour List, 14 April (retrieved from https://labourlist.org/2016/ 04/europe-needs-to-change-but-i-am-voting-to-stay-corbyns-full-speech-on-the-eu/).

Corbyn, J. (2016b), Labour wants EU to reform, says Jeremy Corbyn - video, The Guardian, 16 June (retrieved from https://www.theguardian.com/politics/video/ 2016/jun/16/labour-eu-reform-says-jeremy-corbyn-video).

Cracknell, R., McGuinness, F. and Rhodes, C. (2011), General Election 2010, Parliament.uk, 2 February (retrieved from http://researchbriefings.files.parliament.uk/ documents/RP10-36/RP10-36.pdf).

European Council (2016a), European Council meeting (18 and 19 February 2016) Conclusions (retrieved from http://docs.dpaq.de/10395-0216-euco-conclusions.pdf).

European Council (2016b), European Council, 18.-19. 2. 2016 (retrieved from https://www.consilium.europa.eu/en/meetings/european-council/2016/02/18-19/).

Flood, C. and Usherwood, S. (2007), Ideological Factors in Party Alignments on the EU: A Comparison of Three Cases, EUSA Tenth Biennial International Conference, Montreal, Canada, 17-19 May (retrieved from http://aei.pitt.edu/7875/1/flood-c02c.pdf).

Geddes, A. (2013), Britain and the European Union, London: Palgrave Macmillan.

Gifford, C. (2014), The Making of Eurosceptic Britain, Farnham: Ashgate Publishing Limited.

Goodwin, M. (2016), Corbyn is Cameron's real Brexit headache, Politico, 3 March (retrieved from https://www.politico.eu/article/jeremy-corbyn-gives-david-cameron-more-of-aheadache-than-boris-johnson-on-brexit-referendum/).

Gov.uk (2015), Prime Minister: One nation government backs British farmers (retrieved from https://www.gov.uk/government/news/prime-minister-one-nation-governmentbacks-british-farmers).

Harmsen, R. and Spiering, M. (2004), Introduction: Euroscepticism and the Evolution of European Political Debate, in: Harmsen, R. and Spiering, M. (eds.), Euroscepticism: Party Politics, National Identity and European integration, Amsterdam: Rodopi, pp. 13-35. https://doi.org/10.1163/9789401201087_002

Hawkins, O., Keen, R. and Nakatudde, N. (2015), General Election 2015, Parliament.uk, 28 July (retrieved from http://researchbriefings.files.parliament.uk/documents/CBP7186/CBP-7186.pdf).

Hodson, D. and Maher, I. (2014), British brinkmanship and Gaelic games: EU treaty ratification in the UK and Ireland from a two-level game perspective, British Journal of Politics and International Relations, 16(4), pp. 645-661. https://doi.org/10.1111/1467-856X.12015

Kaniok, P. (2006), Stranický euroskepticismus: Teoretické modely klasifikace politických stran podle opozičních postojů k evropské integraci, in: Havlík, V. and Kaniok, P. (eds.), Euroskepticismus a země střední a východní Evropy, Brno: Mezinárodní politologický ústav, pp. 9-22. 
Kopecký, P. and Mudde, C. (2002), The Two Sides of Euroscepticism: Party Positions on European Integration in East Central Europe, European Union Politics, 3(3), pp. $297-$ 326. https://doi.org/10.1177/1465116502003003002

Labour Party (2015), The Labour Party Manifesto 2015 (retrieved from http://action.labour.org.uk/page/-/A4\%20BIG\%20_PRINT_ENG_LABOUR\%20 MANIFESTO_TEXT\%20LAYOUT.pdf).

Leruth, B., Startin, N. and Usherwood, S. (2018), The Routledge Handbook of Euroscepticism, London: Routledge.

MacMillan, C. (2015), British Political Discourse on the EU in the Context of the Eurozone Crisis, in: Tournier-Sol, K. and Gifford, C. (eds.), The UK Challenge to Europeanization: The Persistence of British Euroscepticism, Basingstoke: Palgrave Macmillan, pp. 191-209. https://doi.org/10.1057/9781137488169_11

Miliband, E. (2014), Ed Miliband's speech on Europe: full text, The Spectator, 12 March (retrieved from https://blogs.spectator.co.uk/2014/03/ed-milibands-speech-oneurope-full-text/).

Miller, V. (2012), The Treaty on Stability, Coordination and Governance in the Economic and Monetary Union: views in other EU Member States, Parliament.uk, 16 April (retrieved from http://researchbriefings.files.parliament.uk/documents/ SN06286/SN06286.pdf).

Oppermann, K. (2008), The Blair government and Europe: the policy of containing the salience of European integration, British Politics, 3(2), pp. 156-182. https://doi.org/10.1057/bp.2008.1

Rettman, A. (2015), Hard-left Corbyn wins Labour vote in UK, Euobserver, 12 September (retrieved from https://euobserver.com/political/130237).

Riishøj, S. (2007), Europeanisation and Euro-scepticism. Experiences from Poland and the Czech Republic, Nationalities Papers, 35(3), pp. 503-535. https://doi.org/10.1080/00905990701368746

Robinson, D. and Shotter, J. (2015), Jean-Claude Juncker calls for creation of EU army, Financial Times, 8 March (https://www.ft.com/content/1141286a-c588-11e4-bd6b00144 feab7de).

Schnapper, P. (2015), The Dilemma of Pro-European Parties in the UK: The Case of Labour and Liberal Democrats Since 2010, in: Tournier-Sol, K. and Gifford, C. (eds.), The UK Challenge to Europeanization: The Persistence of British Euroscepticism, Basingstoke: Palgrave Macmillan, pp. 117-133. https://doi.org/10.1057/9781137488169 7

Szczerbiak, A. and Taggart, P. (2008a), Introduction: Opposing Europe? The Politics of Euroscepticism in Europe, in: Szczerbiak, A. and Taggart, P. (eds.), Opposing Europe? The Comparative Party Politics of Euroscepticism, vol. 1, Case studies and Country Surveys, New York: Oxford University Press, pp. 1-15.

Szczerbiak, A. and Taggart, P. (2008b), Introduction: Researching Euroscepticism in European Party Systems: A Comparative and Theoretical Research Agenda, in: Szczerbiak, A. and Taggart, P. (eds.), Opposing Europe? The Comparative Party 
Politics of Euroscepticism, vol. 2, Comparative and Theoretical Perspectives, New York: Oxford University Press, pp. 1-27.

Szczerbiak, A. and Taggart, P. (2018a), Contemporary research on Euroscepticism: the state of the art, in: Leruth B., Startin N. and Usherwood S. (eds.), The Routledge Handbook of Euroscepticism, London: Routledge.

Szczerbiak, A. and Taggart, P. (2018b), Putting Brexit into perspective: the effect of the Eurozone and migration crises and Brexit on Euroscepticism in European states, Journal of European Public Policy, 25(8), pp. 1194-1214. https://doi.org/10.1080/13501763.2018.1467955

Tournier-Sol, K. and Gifford, C. (2015), Introduction: The Structure of British Euroscepticism, in: Tournier-Sol, K. and Gifford, C. (eds.), The UK Challenge to Europeanization: The Persistence of British Euroscepticism, Basingstoke: Palgrave Macmillan, pp. 1-16. https://doi.org/10.1057/9781137488169_1

Uberoi, E. (2016), European Union Referendum 2016, Parliament.uk, 29 June (retrieved from http://researchbriefings.files.parliament.uk/documents/CBP-7639/CBP-7639.pdf).

Usherwood, S. and Startin, N. (2013), Euroscepticism as a Persistent Phenomenon, Journal of Common Market Studies, 51(1), pp. 1-16. https://doi.org/10.1111/j.1468$\underline{\text { 5965.2012.02297.x }}$

Vasilopoulou, S. (2018), Theory, Concepts and Research Design in the Study of Euroscepticism, in: Leruth B., Startin N. and Usherwood S. (eds.), The Routledge Handbook of Euroscepticism, London: Routledge.

Watt, N. (2015), European commission set to reject David Cameron's migration demands, The Guardian, 5 January (retrieved from https://www.theguardian.com/ politics/2015/jan/05/european-commission-david-reject-cameron-eu-migration). 